\title{
Substitution of Leucaena hay for oil seed cake meal in total mixed rations for goats
}

\author{
K. Leketa, A. Hassen ${ }^{\#}$, E.F. Donkin \& A.M. Akanmu \\ Department of Animal and Wildlife Sciences, University of Pretoria, Private Bag X20, Hatfield 0028, Pretoria, South \\ Africa
}

(Received 19 September 2017; Accepted 12 September 2019; First published online 18 November 2019)

Copyright resides with the authors in terms of the Creative Commons Attribution 4.0 South African Licence.

See: http://creativecommons.org/licenses/by/4.0/za

Condition of use: The user may copy, distribute, transmit and adapt the work, but must recognise the authors and the South African Journal of Animal Science.

\begin{abstract}
This study investigated the effects of incorporating different protein sources (oil seed cakes versus Leucaena leucocephala hay) in a total mixed ration (TMR) on intake, digestibility, growth and carcass meat quality of Saanen goats. Sixteen Saanen male goats were allocated to TMR diets formulated with or without L. leucocephala hay at $25 \%$ of total dry matter (DM). The TMRs were formulated to be iso-nitrogenous, isocaloric and iso-neutral detergent fibre using two sources of crude protein from Leucaena hay or oilseed cake meal (OSCM), which is a blend of soybean, sunflower and cottonseed cake meal. Data were collected on nutrient digestibility and carcass quality parameters. The goats fed TMR with Leucaena had greater $(P$ $<0.05)$ dry matter intake compared with those fed the control diet. In contrast, the digestibility of DM, organic matter, crude protein, neutral detergent fibre, acid detergent fibre and feed conversion ratio did not differ $(P$ $>0.05$ ) between the two dietary treatments. Between treatments, no differences were detected for slaughter bodyweight, empty bodyweight carcass weight, and dressing percentage. Nor were differences detected $(P$ $>0.05$ ) for cooking loss percentage, back fat cover, and area of eye muscle (longissimus dorsi) and WarnerBratzler shear force between goats fed the two TMR diets. Replacing a portion of oilseed cake meal at $15 \%$ DM with Leucaena hay at 25\% DM in TMR for Saanen goats would help rural farmers to reduce the cost of feeding.
\end{abstract}

\footnotetext{
Keywords: body composition, digestibility, feed intake, growth, meat quality

${ }^{\#}$ Corresponding author: abubeker.hassen@up.ac.za
}

\section{Introduction}

Goats play a crucial role in the economy of peri-urban and rural areas in many developing countries, including South Africa (Bester et al., 2009). Often goats are a dominant livestock species in dry regions in which other domestic animals such as cattle do not thrive (Madruga, 2008), because they can utilize the natural vegetation efficiently. Goats also contribute to the rural economy by providing cash income from animal sales, meat for home consumption, and manure, skin and fibre for local use or export (Hassen \& Tesfaye, 2014). Seasonal variations in weather and other environmental constraints often reduce the quality of herbage for the grazing ruminant and consequently affect the production of animals that are raised in these areas (Madruga, 2008). In addition, the present desertification in arid areas and soil erosion contribute to inadequacy of pastures to support animal production without supplementation. In peri-urban and rural areas, use of formulated diets and supplementation with protein sources such as oilseed cake meal could alleviate the problem. Nevertheless, these are beyond the reach of most resource-poor farmers of South Africa. Under these circumstances, locally available and adapted legume trees (Acacia nilotica, Acacia tortilis, and Leucaena leucocephala) can be regarded as alternative feeds to improve goat nutrition and production (Rubanza et al., 2007). However, information about the nutritive value of these feed resources is often limited (Bakshi \& Wadhwa, 2007) and is generally unavailable to farmers in these areas. Leucaena leucocephala is a widely grown tree legume and a popular protein supplement (Aganga \& Tshwenyane, 2003). It is palatable, and thus readily consumed, and highly digestible and has low fibre content (Ha et al., 1995). Leucaena leucocephala can benefit small-scale farmers who cannot afford other expensive protein sources such as soybean and sunflower meals in improving the performance of their animals. It has been shown to improve live weight gain (Rubanza et al., 2007) and milk production (Leketa, 2011) of goats. There is a little information about the comparative nutritional value of Leucaena that is available to farmers in South 
Africa. Thus, the effects were investigated of substituting Leucaena for oilseed cake meal (OSCM) as a protein source in a TMR on feed intake, digestibility, growth performance and carcass quality of Saanen male goats.

\section{Materials and Methods}

The experiment was conducted at the Experimental Farm of the University of Pretoria, Pretoria, Gauteng, South Africa. The area has an altitude of 1339 metres above sea level, annual average temperature of $18.7^{\circ} \mathrm{C}$, and annual average rainfall of $583.1 \mathrm{~mm}$ per year. The use of the goats for this experiment was approved by the Animal Ethics Committee of the University of Pretoria (Reference EC02508). Sixteen castrated 95-day-old male Saanen goats weighing $23 \pm 1.5 \mathrm{~kg}$ were used for the study. Two experimental diets were formulated with two sources of crude protein using the Langston University Goat Research and Extension program (2000). In the first diet, OSCM, composed of a mixture soybean, sunflower and cottonseed cake, was used as a source of protein, while in the second diet OSCM was replaced by Leucaena hay. The experimental diets were iso-caloric, iso-nitrogenous and iso-NDF (Table 1).

Table 1 Ingredients and chemical composition of a total mixed ration in which Leucaena hay replaced a portion of the oil seed cake meal and an iso-caloric and iso-nitrogenous control diet

\begin{tabular}{llll}
\hline Composition, \% dry matter basis & \multicolumn{2}{c}{ Diets $^{1}$} \\
\cline { 2 - 3 }
\end{tabular}

Ingredients

$\begin{array}{lrr}\text { Yellow maize meal } & 22.0 & 27.0 \\ \text { Eragrostis curvula } & 18.0 & 30.0 \\ \text { Leucaena leucocephala } & 25.0 & 0.0 \\ \text { Wheat bran } & 8.0 & 8.0 \\ \text { Cottonseed oil cake meal } & 9.0 & 11.0 \\ \text { Sunflower oil cake meal } & 9.0 & 11.0 \\ \text { Full fat soybean meal } & 0.0 & 4.0 \\ \text { Molasses meal } & 7.0 & 7.0 \\ \text { Mineral mix } & 2.0 & 2.0 \\ \text { Chemical composition } & & 12.0 \\ \text { Crude protein } & 11.9 & 6.0 \\ \text { ASH } & 7.3 & 51.0 \\ \text { Neutral detergent fibre } & 46.5 & \end{array}$

\footnotetext{
${ }^{1}$ TMRL: Leucaena hay and oil seed cake protein, OSCM: oil seed based protein

${ }^{2}$ Limestone flour, salt, di-calcium phosphate, sodium bicarbonate, and vitamin pre-mix
}

Both experimental diets contained $12 \%$ crude protein (CP) and $50 \%$ neutral detergent fibre (NDF) on a DM basis. The Leucaena had previously been harvested three times, in summer and autumn, dried and milled through a 25-mm screen. The harvest included the small twigs on which the leaves were growing to simulate parts of the plant that a goat would be likely to eat when browsing. The other ingredients were purchased on the local market. The experimental diets were mixed thoroughly and fed to the animals as a TMR to minimise selection by the goats and to maximize intake of the roughages in the TMR. The goats were housed individually in cages $(1 \mathrm{~m} \times 75 \mathrm{~cm} \times 1 \mathrm{~m})$ made of welded wire mesh with removable feeders and water troughs. The goats were then stratified according to their initial bodyweight and within strata were randomly allocated to either TMR with Leucaena $(n=8)$ or TMR with OSCM $(n=8)$. The goats had free access to fresh water and feed throughout the experiment. They were fed twice per day at $07 \mathrm{~h} 00$ and $16 \mathrm{~h} 00$. Body conditioning scoring was used to measure the health status of the goats throughout the study. The experiment lasted for a total of 78 days, which consisted of 15 days of adaptation and 63 days of data collection. Dry matter intake (DMI) and average daily gain (ADG) of the castrated Saanen goats were 
recorded. Feed conversion ratio (FCR) was calculated as DMI divided by ADG. To measure ration digestibility, representative samples of feeds offered and refusals were collected daily and bulked weekly. The representative samples of feeds were collected once a day and the refusal samples (orts) were collected twice a day. These bulked samples were later mixed thoroughly and representative subsamples were taken for subsequent laboratory analysis for estimation of DMI and chemical analysis.

Ten castrated male Saanen goats with a mean live weight of $33 \pm 1.8 \mathrm{~kg}$ were used in a digestion trial. Animals were adapted to faecal bags for five days and subsequently urine and faeces were collected for seven days. Orts were removed, measured and recorded daily for each animal. The daily faecal output was collected, weighed, bulked over the seven-day collection period and then kept frozen $\left(-10{ }^{\circ} \mathrm{C}\right)$ prior to laboratory analysis. After the seventh day of collection, the bulked faeces from each goat were mixed thoroughly and approximately $10 \%$ subsamples were dried for $24 \mathrm{hrs}$ at $55{ }^{\circ} \mathrm{C}$ in a hot air oven or until the weight of the sample remained constant. Samples were analysed for DM, ash, organic matter (OM), Nconcentration (Robertson \& Van Soest, 1981). Neutral detergent fibre (NDF), acid detergent fibre (ADF) and acid detergent lignin (ADL) were determined according to the procedures described by Goering \& Van Soest (1970).

At the end of growth and digestion trials, goats were weighed using a Taltec scale (Model 11080LS4H) a day prior to slaughtering to record a final live weight (FLW) measurement. The goats were then fasted by withholding feed for approximately 18 hours, but allowing free access to water. Animals were weighed again the next day to record the live weight at slaughter (SLW). The goats were slaughtered at the abattoir on Hatfield Research Farm of the University of Pretoria. The animals were slaughtered using a captive bolt pistol (humane killing), followed by severing the throat and major blood vessels in the neck. After slaughtering, the head was removed at the atlanto-occipital joint and the blood was drained, then the hind and fore feet were removed at the tarsal-metatarsal joints and carpal-metacarpal joints, respectively. Afterwards, the goats were suspended by the hind legs for further blood draining and skinning. Immediately after skinning and within one hour of slaughter, the carcasses (with kidneys, kidney, and pelvic fat) were weighed to measure hot carcass weight $(\mathrm{HCW})$. However, the weights of non-carcass components were measured separately. These included skin, head, feet, thoracic organs (heart, lungs, and trachea) and viscera (digestive tract, liver, and kidneys). The omental fat was also removed from the viscera and weighed and recorded separately. The gastrointestinal tract (GIT) organs were then weighed with and without the digesta. The weight without digestive contents was subtracted from BW to obtain empty body weight (EBW). Carcasses were weighed to measure warm carcass weight (WCW) and to measure cold carcass weight (CCW) after storage for 24 hours at $5{ }^{\circ} \mathrm{C}$. The commercial dressing percentage based on full bodyweight (FBW) and real dressing percentage based on empty bodyweight (EBW) were calculated as described by Atti et al. (2004).

After 24 hours of refrigeration at $5{ }^{\circ} \mathrm{C}$, drip loss was calculated as the difference between WCW and $\mathrm{CCW}$. The rack and loin cuts were separated between the 11th and 13th ribs. The cross-sectional surface of the longissimus dorsi muscle between the 11th and 13th ribs was traced, and the eye muscle area in $\mathrm{cm}^{2}$ was subsequently measured using a grid. Back fat depth was measured on left side at the 11th-13th ribs and rump using a calliper. The tissues over these cuts were then dissected separately (lean, subcutaneous and inter muscular fat and bone) and weighed to obtain percentages of muscle, fat and bone. The samples of lean meat were removed and weighed, and then sealed in polythene bags and cooked in a thermostatically controlled water bath (Merck model 207) at $75{ }^{\circ} \mathrm{C}$ for approximately one hour. The samples were dried with a paper towel, cooled and stored at $4{ }^{\circ} \mathrm{C}$ overnight. The next day each sample was dried with a paper towel again and weighed. Cooking loss was determined as the difference between the weight of the sample before cooking and the weight after it had been chilled and dried. The cooked samples were then used to measure shear force. Cores were cut parallel to the myofibres from each sample and each core was sheared perpendicularly to the myofibres using Warner-Bratzler blades on an Instron universal testing machine (Model 1011 Instron Ltd, England). The average shear force for each sample of meat was determined and recorded.

The general linear model procedure of SAS (version 9.1, SAS Institute Inc., Cary, NC, USA) was used to analyse the data. As appropriate for a completely randomized design, the growth, feed intake, nutrient digestibility and carcass quality traits were modelled as a function of the treatment effect. The data were presented as the mean of each treatment and the associated standard errors. When the treatment effect was significant, the means were compared using Student's $t$-test.

\section{Results and Discussion}

Table 2 shows the bodyweights, ADG, DMI and FCR of castrated Saanen goats fed TMR with or without Leucaena. At the commencement of the experiment the goats had similar initial weight $(23 \pm 2.5 \mathrm{~kg})$. 
Table 2 Body weight, body weight gain, feed intake, and feed conversion ratio of castrated Saanen goats fed a total mixed ration in which Leucaena hay replaced a portion of the oil seed cake meal and an iso-caloric and iso-nitrogenous control diet

\begin{tabular}{|c|c|c|c|c|}
\hline Trait & TMRL & OSCM & \pm SE & $P$-value \\
\hline Initial bodyweight (kg) & 22.9 & 23.1 & \pm 1.50 & 0.95 \\
\hline Final bodyweight (kg) & 29.3 & 28.9 & \pm 2.27 & 0.65 \\
\hline Bodyweight gain (kg) & 6.4 & 5.8 & \pm 1.66 & 0.14 \\
\hline Average gain (g/head/day) & 101.6 & 92.1 & \pm 10.35 & 0.14 \\
\hline Dry matter intake (g/head/day) & $995.0^{\mathrm{a}}$ & $865.0^{\mathrm{b}}$ & \pm 43.00 & 0.04 \\
\hline Feed conversion ratio & 10.0 & 11.5 & \pm 2.37 & 0.14 \\
\hline
\end{tabular}

${ }^{\mathrm{a}, \mathrm{b}}$ Row means followed by different superscript letters are significantly different at $P<0.05$

TMRL: Leucaena hay and oil seed cake protein, OSCM: oil seed based protein

The final weights (29.3 vs $28.9 \pm 2.27 \mathrm{~kg})$ and ADG (101.6 vs $92.1 \pm 10.35 \mathrm{~g} / \mathrm{head} / \mathrm{day})$ of the goats fed TMR with Leucaena and of the goats fed the control diet were not different $(P>0.05)$. Generally, a slight decrease in mean BW was observed in both groups during the first week, but after that there was a steady increase weight for the goats on both experimental diets. During the growth trial, goats fed TMR with Leucaena consumed $(P<0.05)$ more feed than those fed TMR without Leucaena. However, FCR was not different $(P>0.05)$ between the two TMR diets. The observed tendency for greater DMI of goats fed TMR with Leucaena compared with the goats fed TMR without Leucaena is consistent with the findings of other researchers. Rubanza et al. (2007) reported greater DMI of a Leucaena-supplemented diet compared with diets that were supplemented with Acacia nilotica, Acacia polyacantha, and a diet composed of a 'native pasture' hay plus $100 \mathrm{~g}$ maize bran. Leucaena-supplemented diets were also consumed more readily than TMR that incorporated soybean meal (Srivastava \& Sharma, 1998; Anbarasu et al., 2004). This may be because of the palatability and CP digestibility of Leucaena (Rubanza et. al., 2007). In the present study, the goats fed the TMR with Leucaena on average consumed $79 \mathrm{~g} \mathrm{DM} / \mathrm{kgW}^{0.75}$ compared with $75.1 \mathrm{~g}$ DM $/ \mathrm{kgW}^{0.75}$ for the goats that were fed the control diet. These results for DM intake were similar to the findings of Srivastava \& Sharma (1998), who on average observed the consumption of $72.11 \mathrm{~g} \mathrm{DM} / \mathrm{kgW}^{0.75}$ for adult Jamunapari goats fed pelleted sundried Leucaena. In this study, replacing OSCM with Leucaena did not alter the weight gain of goats. In contrast, greater weight gains were reported in other studies that used Leucaena meal as a protein source as opposed to conventional diets (Mahanta et al., 1999; Anbarasu et al., 2004). Leucaena has been reported to have a low to medium level of tannins, which protect protein from degradation in the rumen (Anbarasu et al., 2004). This may be important for protein to by-pass the rumen and flow to the intestine. The numerically reduced weight gain of goats fed the TMR without Leucaena compared with goats fed the TMR with Leucaena may have resulted in numerically lower FCR of the goats fed TMR without Leucaena compared with those fed TMR with Leucaena. Furthermore, Leucaena has shown to be utilized more effectively by goats than leaf meal of other leguminous plants (Yousuf et. al., 2007).

There were no differences $(P>0.05)$ between the two TMRs diets in apparent digestibility of DM, OM, CP, NDF, and ADF (Table 3). However, the estimates of digestibility of all components in the TMR diets without Leucaena were numerically greater than for the TMR with Leucaena.

During the digestion trial, goats fed TMR with Leucaena had greater $(P<0.01)$ DMI and organic matter intake compared with goats fed the control diet (Table 4). Consumption of CP, NDF, and ADF by goats fed TMR without Leucaena was less than $(P<0.05)$ that of goats fed TMR with Leucaena. These observations were consistent, whether expressed per day or per kg of bodyweight. The greater intake of TMR with Leucaena could be associated with the palatability of that diet. 
Table 3 Apparent digestibility (\%) for components of total mixed rations with or without Leucaena fed to castrated Saanen goats $(n=5 /$ diet)

\begin{tabular}{lcccc}
\hline Component & TMRL & OSCM & \pm SE & $P$-value \\
\hline Dry matter & 65.6 & 67.7 & \pm 1.45 & 0.18 \\
Organic matter & 65.0 & 69.8 & \pm 1.45 & 0.09 \\
Crude protein & 58.6 & 62.0 & \pm 2.02 & 0.20 \\
Neutral detergent fibre & 56.2 & 60.6 & \pm 1.93 & 0.30 \\
Acid detergent fibre & 50.6 & 51.8 & \pm 2.40 & 0.82
\end{tabular}

TMRL: Leucaena hay and oil seed cake protein, OSCM: oil seed based protein

Table 4 Voluntary feed intake of total mixed rations with or without Leucaena hay fed to castrated Saanen goats $(n=5 /$ diet $)$ during a seven-day digestion trial

\begin{tabular}{|c|c|c|c|c|c|c|c|c|}
\hline \multirow{2}{*}{ Component } & \multicolumn{4}{|c|}{ Voluntary intake (g/kg/day) } & \multicolumn{4}{|c|}{ Voluntary intake (g/kg BW ${ }^{0.75} /$ day) } \\
\hline & TMRL & OSCM & $\pm \mathrm{SE}$ & $P$-value & TMRL & OSCM & \pm SE & $P$-value \\
\hline Dry matter & $1102.4^{\mathrm{a}}$ & $741.0^{\mathrm{b}}$ & \pm 76.5 & 0.01 & $78.5^{a}$ & $56.2^{\mathrm{b}}$ & \pm 4.30 & 0.01 \\
\hline Organic matter & $1022.0^{\mathrm{a}}$ & $696.6^{\mathrm{b}}$ & \pm 65.8 & 0.01 & $72.9^{a}$ & $52.7^{\mathrm{b}}$ & \pm 4.26 & 0.02 \\
\hline Crude protein & $131.0^{\mathrm{a}}$ & $89.6^{\mathrm{b}}$ & \pm 9.1 & 0.01 & $9.4^{\mathrm{a}}$ & $6.8^{\mathrm{b}}$ & \pm 0.56 & 0.01 \\
\hline Neutral detergent fibre & $517.0^{\mathrm{a}}$ & $381.8^{\mathrm{b}}$ & \pm 36.0 & 0.03 & $36.7^{\mathrm{a}}$ & $28.8^{\mathrm{b}}$ & \pm 1.98 & 0.04 \\
\hline Acid detergent fibre & $300.0^{\mathrm{a}}$ & $197.6^{\mathrm{b}}$ & \pm 22.3 & 0.01 & $21.4^{\mathrm{a}}$ & $15.0^{\mathrm{b}}$ & \pm 1.33 & $<0.01$ \\
\hline
\end{tabular}

$\overline{a, b}$ Within trait, row means followed by different superscript letters are significantly different

TMRL: Leucaena hay and oil seed cake protein, OSCM: oil seed based protein

In contrast to the gross voluntary intake of nutrients, intakes expressed on a digestible basis were more nearly similar for both diets (Table 5 ). Despite the greater gross intake of organic matter, the daily consumption of digestible organic matter of the TMR with Leucaena was less than $(P<0.05)$ that of the control TMR. Consumption of the various dietary components, which was expressed relative to metabolic bodyweight, of goats fed TMR with Leucaena was not different $(P>0.05)$ from those fed TMR without Leucaena.

Table 5 Voluntary intake for digestible components of total mixed rations with or without Leucaena hay fed to castrated Saanen goats $(n=5 /$ diet) during a seven-day digestion trial

\begin{tabular}{lrrrrrrrr}
\hline \multirow{2}{*}{ Component } & \multicolumn{3}{c}{ Digestible intake (g/goat/day) } & \multicolumn{3}{c}{ Digestible intake $(\mathrm{g} / \mathrm{kg} \mathrm{BW}$ B.75/day) } \\
\cline { 2 - 9 } & TMRL & OSCM & SE & P-value & TMRL & OSCM & SE & $P$-value \\
\hline \multirow{2}{*}{ Organic matter } & $604.0^{\mathrm{a}}$ & $656.0^{\mathrm{b}}$ & \pm 13.2 & 0.04 & 43.7 & 49.4 & \pm 2.0 & 0.15 \\
Crude protein & 71.5 & 77.1 & \pm 2.6 & 0.20 & 5.0 & 5.8 & \pm 0.3 & 0.20 \\
Neutral detergent fibre & 157.1 & 137.6 & \pm 17.7 & 0.15 & 19.0 & 23.8 & \pm 1.3 & 0.06 \\
Acid detergent fibre & 138.8 & 137.6 & \pm 7.4 & 0.94 & 10.0 & 10.4 & \pm 0.7 & 0.79 \\
\end{tabular}

${ }^{a, b}$ Within traits, row means followed by different superscript letters are significantly different
TMRL: Leucaena hay and oil seed cake protein, OSCM: oil seed based protein, BW: body weight

The total mixed ration without Leucaena had greater digestible organic matter intake $(P<0.05)$ than the TMR with Leucaena hay. This may be attributable to the secondary metabolites that were present in the Leucaena, which can impede microbial degradation. D'Mello (1992) indicated that Leucaena leaves contain 
moderate amounts (30-43 $\mathrm{g} / \mathrm{kg}$ ) of condensed tannins (proanthocyanidine). This plant compound can result in a positive or adverse effect on the nutritive value of forage and N-utilization (Srivastava \& Sharma, 1998). Although, this substance was not measured in this study, it is pertinent to consider its potential effects in interpreting the data. Maasdorp et al. (1999) stated that despite a high CP content in leguminous trees, they can have a high level of polyphenolic compounds, which can bind the protein and make it unavailable to animals consuming it. However, they can have a beneficial effect as they can protect protein from rumen degradation, and hence increase rumen escape protein, which decreases ammonia loss (Norton, 1994). The results obtained in this study regarding the lower digestibility of the Leucaena diet compared with other diets have been reported by other researchers (Babayemi \& Bamikole, 2006; Hassen, 2006). Depression in the digestibility of nutrients in this study, regardless of high DM and other nutrient intake, could be associated with the length of time that the feed is exposed to rumen activity by microbes and enzymes (Van Soest, 1994) and the presence of mimosine, an anti-nutritional factor that is found in Leucaena and is capable of influencing rumen microbes activities.

Carcass characteristics (Table 6) showed that goats fed both TMR diets attained approximately equivalent SLW and EBW. Similarly, WCW and CCW did not differ among goats fed on the two TMR diets $(P$ $>0.05)$. Thus, including Leucaena in diets of goats had no effect $(P>0.05)$ on their dressing percentages or the difference between WCW and CCW. The real dressing percentage ranged from $50.5 \%$ to $52.6 \%$ in the present study. This appeared to be slightly less for the goats fed on the control TMR as compared with the goats fed TMR with Leucaena. The range in values agrees with previous reports (El Khidir, 1998; Dhanda et al., 2003; Ryan et al., 2007).

Table 6 Slaughter body weight, empty body weight, carcass weight, dressing percentage and drip loss of castrated Saanen goats fed total mixed rations with or without Leucaena hay

\begin{tabular}{lcccc}
\hline Trait & TMRL & OSCM & \pm SE & $P$-value \\
\hline Slaughter bodyweight (kg/goat, SLW) & 29.4 & 27.5 & \pm 2.6 & 0.67 \\
Empty bodyweight (kg/goat, EBW) & 26.5 & 24.5 & \pm 2.2 & 0.79 \\
Warm carcass weight $_{\text {Cold carcass weight }}$ & 13.3 & 12.7 & \pm 1.2 & 0.89 \\
Commercial dressing pecentage $^{1}$ & 12.6 & 11.9 & \pm 1.2 & 0.90 \\
Real dressing percentage $^{1}$ & 54.9 & 54.3 & \pm 0.9 & 0.64 \\
& 52.6 & 50.5 & \pm 0.9 & 0.61
\end{tabular}

${ }^{1}$ Dressing percentages calculated as described by Atti et al. (2004)

TMRL: Leucaena hay and oil seed cake protein, OSCM: oil seed based protein

There were no differences $(P>0.05)$ in terms of non-carcass components (head, skin, and feet), visceral organs (heart, kidney, lungs liver and spleen) gastro-intestinal tract and fat content between goats fed TMRs with or without Leucaena (Table 7). Similarly, data recorded for the 11th-13th ribs and thoracic vertebra and associated muscle and fat were not different (Table 8). Replacing OSCM with Leucaena as protein source affected the muscle to bone (2.2 vs. 2.3) and muscle to fat ratios (3.2 vs. 3.1) of goats fed TMRs with or without Leucaena. The proportions of various visceral organs, sections of the digestive tract and non-carcass components were similar and were in the same range as those reported by other researchers for various breeds at the same age and live weight, but that were offered different diets (Johnson et al., 1995; Marichal et al., 2003; Dhanda et al., 2003).

There are limited reports of research to evaluate the effect of Leucaena and other leguminous trees on the carcass characteristics of goats. However, the results of this present study were similar to what was reported when goats were introduced to TMR based on commercial diets (Marichal et al., 2003). Here, it was demonstrated that including Leucaena in the TMR had no effect on the loin eye muscle area for goats fed TMR with Leucaena compared with goats fed the TMR without Leucaena (Table 8). The back-fat cover on the longissimus dorsi muscle was similar for the goats fed the two TMRs. Similar values were reported by Dhanda et al. (2003), although the values of the present study were slightly higher. The thin layer of subcutaneous fat in the present study confirmed the report by Dhanda et al. (2003). The appearance of fat in the carcass might be more acceptable in the market value for small stock. According to Webb et al. (2005) subcutaneous fat thickness of $1-4 \mathrm{~mm}$ is the optimum range that is suggested for flavour and hence acceptability to the consumers. Dhanda et al. (2003) reported similar values for Saanen x Alpine goats, but 
this value was slightly lower than the values reported by these authors for other breeds such as Boer $x$ Angora and Boer $x$ feral goats.

Table 7 Weights of visceral organs and non-carcass components of castrated Saanen goats fed total mixed rations with or without Leucaena hay

\begin{tabular}{|c|c|c|c|c|}
\hline Trait & TMRL & OSCM & $\pm \mathrm{SE}$ & $P$-value \\
\hline Head & 1.50 & 1.49 & \pm 0.12 & 0.77 \\
\hline Skin & 1.90 & 2.00 & \pm 0.12 & 0.89 \\
\hline Feet & 0.70 & 0.68 & \pm 0.06 & 0.79 \\
\hline Digestive tract (kg/goat) & 3.10 & 3.30 & \pm 0.24 & 0.88 \\
\hline Digestive tract $(\mathrm{g} / \mathrm{kg} \mathrm{BW})$ & 10.60 & 12.40 & \pm 0.66 & 0.60 \\
\hline Reticulo-rumen & 1.00 & 1.10 & \pm 0.08 & 0.90 \\
\hline Intestine & 1.25 & 1.31 & \pm 0.11 & 0.66 \\
\hline Heart & 0.09 & 0.89 & \pm 0.81 & 0.79 \\
\hline Kidney & 0.07 & 0.08 & \pm 0.02 & 0.79 \\
\hline Lungs & 0.19 & 0.21 & \pm 0.08 & 0.88 \\
\hline Liver & 0.38 & 0.41 & \pm 0.02 & 0.70 \\
\hline Spleen & 0.04 & 0.06 & \pm 0.06 & 0.66 \\
\hline Omental fat & 1.65 & 1.71 & \pm 0.17 & 0.87 \\
\hline Kidney and pelvic fat & 0.62 & 0.68 & \pm 0.02 & 0.75 \\
\hline
\end{tabular}

TMRL: Leucaena hay and oil seed cake protein, OSCM: Oil seed based protein, BW: Body weight

Table 8 Carcass traits and composition of a section obtained at the $11^{\text {th }} 13^{\text {th }}$ ribs of castrated Saanen goats fed total mixed rations with or without Leucaena hay

\begin{tabular}{lrrrc}
\hline Parameter & TMRL & OSCM & \pm SE & $P$ value \\
\hline 11th-13th rib section weight (g) & 269.0 & 251.4 & \pm 27.4 & 0.66 \\
Muscle (\%) & 56.1 & 56.5 & \pm 1.5 & 0.87 \\
Bone (\%) & 26.0 & 25.4 & \pm 1.4 & 0.76 \\
Fat (\%) & 18.1 & 18.5 & \pm 1.8 & 0.88 \\
Muscle/bone ratio & 2.2 & 2.3 & \pm 0.1 & 0.76 \\
Muscle/fat ratio & 3.2 & 3.1 & \pm 0.3 & 0.66 \\
Muscle eye (cm) & 8.9 & 9.9 & \pm 0.8 & 0.38 \\
Back fat thickness (mm) & 2.9 & 2.9 & \pm 0.5 & 0.91
\end{tabular}

TMRL: Leucaena hay and oil seed cake protein, OSCM: Oil seed based protein

No significant differences were observed for the ratios of muscle to bone or muscle to fat of the goats fed TMR with Leucaena compared with those fed the control (Table 8). The observed percentages of dissected muscle (56\%), bone (26\%), and fat (18\%) agreed with the findings of Marichal et al. (2003) for dairy goat breeds and those reported by El Khidir et al. (1998) for desert Sudanese goats. However, the fat content of goats in this study was greater than the values recorded by Marichal et al. (2003), who reported $11 \%$ of total fat. However, the current fat percentage was consistent with the observations by El Khidir et al. (1998) for desert Sudanese goats. The muscle to bone ratio of 2.2: 1 in this study was similar to that found for Canary Caprine male dairy goats, which had a muscle to bone ratio of 2.09: 1 (Marichal et al., 2003) and for male black goats, which had ratio of 2.2: 1 (Abdullah \& Musallam, 2007), even though these goats were raised in different systems of rearing and management. However, the muscle to bone ratio observed in this study was less than value of 3.0: 1 that was reported for Sudanese desert breeds (El Khidir et al., 1998). The 
ratio of muscle to fat of 3.1: 1 in this study differed considerably from that of $2.5: 1$, which was reported by Abdullah \& Musallam (2007) for male black goats.

No significant differences were observed in drip loss, cooking loss or shear force of the longissimus dorsi muscle for goats fed TMR with the Leucaena compared with the control TMR (Table 9). The present observations of shear force were less than the values reported by Kannan et al. (2006), who recorded 3.15$3.48 \mathrm{~kg} / \mathrm{cm}^{2}$ in the loin/rib chops of Saanen goats fed dietary treatments that differed in energy and protein levels; of Kadim et al. (2003), who recorded $7.2-7.7 \mathrm{~kg} / \mathrm{cm}^{2}$ ) for the longissimus muscle of Omani goat breeds; and of Ryan et al. (2007) who recorded 5.3-5.8 kg in longissimus muscle of Boer crossbred goats fed different levels of dietary concentrates. However, the present results were consistent with values recorded by Abdullah \& Musallam (2007) for the longissimus muscle of castrated and intact male goats (1.9$2.3 \mathrm{~kg} / \mathrm{cm}^{2}$ ) fed different levels of energy. Shear force may vary considerably owing to various factors, including nutrition, treatment of the animal prior to slaughter and the carcass after slaughter, preparation of samples, age, temperature during cooking, $\mathrm{pH}$, and types of muscle that were used (Webb et al., 2005). In general, Warner-Bratzler shear force (WBSF) values that are above $5.5 \mathrm{~kg}$ are considered to indicate tough meat that should not be accepted in the market (Johnson et al., 1995). Abdullah \& Musallam (2007) suggested that shear force values below $3.6 \mathrm{~kg}$ should be considered to fall within the range of acceptable tenderness for goat and sheep meat. Therefore, the values obtained in this study showed that meat from castrated Saanen goats fed TMR with or without Leucaena would be acceptable to the market. Cooking loss is an indication of meat juiciness during eating (Webb et al., 2005), and therefore would reflect acceptance of that meat to the consumers. The cooking loss in the present study ranged from $26 \%$ to $27 \%$, but the differences were not significant (Table 9). Kannan et al. (2006) indicated that neither the protein nor energy level had an effect on the cooking loss of loin/rib of goats. Similarly, Abdullah \& Musallam (2007) found that there was no effect of feed energy level on cooking loss of $m$. longissimus dorsi of male black goats. The cooking loss obtained in this study was within the range of values reported by Dhanda et al. (2003) for BoerSaanen breeds and by Abdullah \& Musallam (2007) for black goats. However, the values obtained in this study are higher than those recorded by Kannan et al. (2006), who found a range from $16 \%$ to $20.8 \%$ using castrated Saanen goats fed different diets. Contrarily the values in this study were lower than the findings by Dhanda et al. (1999), who recorded values in the range of $34 \%$ to $39 \%$ on $\mathrm{m}$. longissimus dorsi for five genotypes, including Saanen crosses. These differences may be attributable to cooking losses being influenced by many factors, including $\mathrm{pH}$, cooking conditions, and types of muscle (Abdullah \& Musallam, 2007).

Table 9 Carcass quality characteristics of castrated Saanen goats fed total mixed rations with or without Leucaena hay

\begin{tabular}{lcccc}
\hline Trait & TMRL & OSCM & \pm SEM & $P$ value \\
\hline Drip loss (kg/goat) & 0.7 & 0.8 & \pm 0.1 & 0.79 \\
Cooking loss (\%) & 27.4 & 25.9 & \pm 2.0 & 0.61 \\
Shear force (N) & 18.2 & 17.4 & \pm 1.4 & 0.71
\end{tabular}

TMRL: Leucaena hay and oil seed cake protein, OSCM: Oil seed based protein

\section{Conclusion}

Including Leucaena in the TMR increased the feed intake of goats, presumably because of improved palatability. However, differences between diets in bodyweight gain, feed conversion ratio, and meat production and quality were not detectable. Incorporation of $25 \%$ Leucaena could replace other protein sources to balance the diet of meat goats.

\section{Acknowledgements}

This project was completed with the financial support from the Department of Agriculture Forestry and Fisheries (DAFF), and their support is gratefully acknowledged. In addition, we would like to thank the staff of Hatfield Research Farm and Nutrilab in the Department of Animal and Wildlife Sciences for their assistance.

\section{Authors' Contributions}

$\mathrm{KL}, \mathrm{EFD}$ and $\mathrm{AH}$ designed the study, while it was implemented (sample collection and data analysis) by $\mathrm{KL}$. Both EFD and $\mathrm{AH}$ participated in interpretation of results and, statistical analysis. KL wrote the draft while EDF, AH and AMA edited and proofread it. 


\section{Conflict of Interest Declaration} None.

\section{References}

Abdullah, Y.A.. \& Musallam, S.H., 2007. Effects of different levels of energy on carcass composition and quality of male black goat's kids. J. Livestock Sci. 107, 70-80.

Aganga, A.A. \& Tshwenyane, S.O., 2003. Lucerne, Lablab and Leucaena leucocephala forages: Production and utilisation for livestock production. J. Nutrition 2, 46-53.

Anbarasu, C., Dutta, N., Sharma, K. \& Rawat, M., 2004. Response of goats to partial replacement of dietary protein by a leaf meal mixture containing Leucaena leucocephala, Morus alba and Tectona grandis. Small Rumin. Res. 51, 47-56.

Atti, N., Rouissi, H. \& Mahouachi, M., 2004. The effect of dietary crude protein level on growth, carcass and meat composition of male goat kids in Tunisia. Small Rumin. Res. 54, 89-97.

Babayemi, J. \& Bamikole, M., 2006. Supplementary value of Tephrosia bracteolata, Tephrosia candida, Leucaena leucocephala and Gliricidia seium hay for West African Dwarf goats kept on range. Central Europe. Agr. 7, 323328.

Bakshi, M.P.S. \& Wadhwa, M., 2007. Tree leaves as complete feed for goat bucks. Small Rumin. Res. 69, 74-78.

Bester, J., Ramsay, K.A. \& Scholtz, M.M., 2009. Goat farming in South Africa: Findings of a national livestock survey. Applied Animal Husbandry \& Rural Development 2009 (2), 13.

D'Mello, J.P.F., 1992. Chemical constraints to the use of tropical legumes in animal nutrition. Anim. Feed Sci. Technol. 38, 237-261.

Dhanda, J.S., Taylor, D. G. \& Murray, P.J., 2003. Part1. Growth, carcass and meat quality parameters of male goats: Effect of genotype and live weight at slaughter. Small Rumin. Res. 50, 57-66.

Dhanda, J.S., Taylor, D. G., Murray, P.J. \& McCosker, J.E., 1999. The influence of goat genotype on the production of Capretto and chevon carcasses to meat quality. Meat Sci. 52, 363-367.

El Khidir, I.A., Babiker, S.A. \& Shafie, S.A., 1998. Comparative feedlot performance and carcass characteristics of Sudanese Sheep and Goats. Small Rumin. Res. 30, 147-151.

Goering, H.K. \& Van Soest, P.J., 1970. Forage fiber analysis (apparatus, reagents, procedures and some applications). In: Agric. Handbook No. 379. Agric. Res. Serv. USA Dept. of Agric., Washington, USA.

Ha, N.N., Phan, P.T., Khai, H.M. \& Viet, N.B. 1995. Leucaena as protein supplemental feed for milking cows and growing goats. National Inst. of Anim. Husbandry, 101-105.

Hassen, A., 2006. Characterization and evaluation of indigofera species as potential cover crops for semi-arid and arid ecosystems. Ph.D. thesis, Faculty of Natural and Agricultural Science, University of Pretoria, South Africa.

Hassen, A.S. \& Tesfaye, Y., 2014. Sheep and goat production objectives in pastoral and agro-pastoral production systems in Chifra district of Afar, Ethiopia. Trop. Anim. Health Prod., 46(6), 1467-1474

Johnson, D.D., McGowan, C.H., Nurse, G. \& Anous, M.R., 1995. Breed type and sex effects on carcass traits, composition and tenderness of young goats. Small Rumin. Res. 17, 57-63.

Jones, R.J. \& Megarrity R.G., 1986. Successful transfer of DHP-degrading bacteria from Hawaiian goats to Australian ruminants to overcome the toxicity of Leucaena. Aust. Vet. J. 63, 259-262.

Kadim, I.T., Mahgoub, O., Al-Ajmi, D.S., Al-Maqbaly, R.S., Al-Saqri, N.M. \& Ritchie, A., 2003. An evaluation of the growth, carcass and meat quality characteristics of Omani goat breeds. Meat Sci. 66, 203-210.

Kannan, G., Gadiyaram, K.M., Galipalli, S., Carmichael, A., Kouakou, B., ..., Gelaye, S., 2006. Meat quality in goats as influenced by dietary protein and energy levels, and post-mortem aging. Small Rumin. Res. 61, 45-52.

Langston University Goat Research and Extension Programs, 2000. Langston University Agricultural Research and Extension Programs, Langston, Oklahoma, USA.

Laudadio, V. \& Tufarelli, V., 2010. Effects of pelleted total mixed rations with different rumen degradable protein on milk yield and composition on Jonica dairy goat. Small Rumin. Res. 90, 47-52.

Leketa, K., 2011. Milk goat feeding systems using Leucaena leucocephala in total mixed rations. MSc. (Agric.) dissertation, Faculty of Natural and Agricultural Science, University of Pretoria, South Africa.

Maasdorp, B.V., Muchenje, V. \& Titterton, M., 1999. Palatability and effects on dairy cow milk yield of dried fodder from the forage trees Acacia boliviana, Calliandra calothyrsus and Leucaena leucocephala. Anim. Feed Sci. Technol. 77, 49-59

Madruga, M.S., Torres T.S., Carvalho, F.F., Queiroga, R.C., Narain, N., .., Costa, R.G., 2008. Meat quality of Moxoto and Caninde goats as affected by two levels of feeding. Meat Science 80, 1019-1023.

Mahanta, S. K., Singh, S. \& Pachauri, V.C., 1999. Subabul leaf meal as replacement of mustard cake in lamb diets. Small Rumin. Res. 32, 37-42.

Marichal, A., Castro, N., Capote, J., Zamorano, M.J. \& Arguello, A., 2003. Effect of live weight at slaughter (6, 10 and $25 \mathrm{~kg}$ ) on kid carcass and meat quality. Livestock Prod. Sci. 83, 247-256.

Norton, B.W., 1994. The nutritive value of tree legumes. In: R.C. Gutteridge \& H.M. Shelton (eds), 1994. Forage tree legumes in tropical agriculture. CAB, Willingford, Oxan, UK, pp. 192-201.

Richards, D. E., Brown, W.F., Ruegsegger, G. \& Bates, D.B., 1994. Replacement value of tree legumes for concentrates in forage-based diets II. Replacement value of Leucaena and Gliriadia sepium for lactating goats. Anim. Feed Sci. Technol. 46, 53-65.

Robertson, J. B., \& Van Soest, P. J., 1981. The detergent system of analysis and its application to human foods. In: W.P.T. James and O. Theander, The Analysis of Dietary Fiber in Food Marcel Dekker, New York, pp. 123-158. 
Rubanza, C.D.K., Shem, M.N., Bakengesa, S.S., Ichinohe, T. \& Fujihara, T., 2007. Effect of Acacia nilotica, A. polyacantha and Leucaena leucocephala leaf meal supplementation on performance of Small East African goats fed native pasture hay basal forages. Small Rumin. Res. 70, 165-173.

Ryan, S.M., Unruh, J.A., Corrigan, M.E., Drouillard, J.S. \& Seyfert, M., 2007. Effect of concentrate level on carcass traits of Boer crossbred goats. Small Rumin. Res. 73: 67-76.

Samuels, M.L. 1989. Statistics for the life sciences. Collier Macmillan, London.

Srivastava, S.N.L. \& Sharma, K., 1998. Response of goats to pelleted diets containing different proportions of sun-dried Leucaena leucocephala. Small Rumin. Res. 28, 139-148.

Van Soest, P.J., 1994. Nutritional ecology of the ruminant. 2nd edition. Cornell University Press, Ithaca, NY, USA.

Webb, E.C., Casey, N.L. \& Simela, L., 2005. Goat meat quality. Small Rumin. Res. 60, 153-166.

Yousuf, M.B., Belewu, M.A., Daramola, J.O. \& Ogundun, N.I., 2007. Protein supplementary values of cassava, Leucaena and Gliricidia leaf meals in goats fed low quality Panicum maxium hay. Livestock Res. Rural Develop. 19, 2. 